This item was submitted to Loughborough's Research Repository by the author.

Items in Figshare are protected by copyright, with all rights reserved, unless otherwise indicated.

\title{
Synthesis and structural characterization of Dinuclear Cerium(III) and Erbium(III) complexes of Nicotinic acid or 2-Aminobenzoic acid
}

PLEASE CITE THE PUBLISHED VERSION

https://doi.org/10.1016/j.poly.2018.05.057

\section{PUBLISHER}

(C) Elsevier

\section{VERSION}

AM (Accepted Manuscript)

\section{PUBLISHER STATEMENT}

This work is made available according to the conditions of the Creative Commons Attribution-NonCommercialNoDerivatives 4.0 International (CC BY-NC-ND 4.0) licence. Full details of this licence are available at: https://creativecommons.org/licenses/by-nc-nd/4.0/

\section{LICENCE}

CC BY-NC-ND 4.0

\section{REPOSITORY RECORD}

Hussain, Sajjad, Islam Ullah Ullah Khan, Mark Elsegood, Nadia Jabeen, Muhammad Nawaz Tahir, Saeed Ahmad, and Sadaf Mutahir. 2019. "Synthesis and Structural Characterization of Dinuclear Cerium(iii) and Erbium(iii) Complexes of Nicotinic Acid or 2-aminobenzoic Acid”. figshare. https://hdl.handle.net/2134/33511. 


\title{
Synthesis and Structural Characterization of DinuclearCerium(III) and Erbium(III) Complexes of Nicotinic Acid or 2-Aminobenzoic Acid
}

\author{
Sajjad Hussain, ${ }^{\mathrm{a}, \mathrm{b} *}$, Islam Ullah Khan ${ }^{\mathrm{a}}$, Mark R. J. Elsegood ${ }^{\mathrm{c}}$, Nadia Jabeen ${ }^{\mathrm{d}}$, Muhammad Nawaz \\ Tahir $^{\mathrm{e}}$, Saeed Ahmad ${ }^{\mathrm{f}}$, Sadaf Mutahir ${ }^{\mathrm{a}}$
}

${ }^{a}$ Materials Chemistry Laboratory, Department of Chemistry, Government College University, Lahore 54000, Pakistan

${ }^{\mathrm{b}}$ Department of Chemistry, Mohi-ud-Din Islamic University, Nerian Sharif, Azad Jammu \& Kashmir, Pakistan

${ }^{c}$ Chemistry Department, Loughborough University, Loughborough, Leicestershire, LE113TU United Kingdom-M.R.J.Elsegood@lboro.ac.uk

${ }^{\mathrm{d}}$ Department of Chemistry, University of Engineering and Technology, Lahore 54890, Pakistan ${ }^{\mathrm{e}}$ Department of Physics, University of Sargodha, Sargodha, Pakistan

${ }^{\mathrm{f}}$ Department of Chemistry, College of Sciences and Humanities, Prince Sattam bin Abdulaziz University, Al-Kharj 11942, Saudi Arabia

\begin{abstract}
A cerium(III) complex, $\left[\mathrm{Ce}_{2}(\mathrm{NA})_{6}\left(\mathrm{H}_{2} \mathrm{O}\right)_{4}\right] \quad$ (1) and anerbium(III) complex, $\left[\mathrm{Er}_{2}(2-\right.$ $\left.\mathrm{AMB})_{6}\left(\mathrm{H}_{2} \mathrm{O}\right)_{4}\right] \cdot 3 \mathrm{H}_{2} \mathrm{O}(2)$, where $\mathrm{NA}=$ nicotinic acid and 2-AMB $=2$-aminobenzoic acid, have been prepared and characterized by IR spectroscopy, thermogravimetric analysis and X-ray crystallography. The single crystal analysis reveals that both complexes are dinuclear. In $\mathbf{1}$, the two cerium(III)ions are bridged by carboxylate groups of four nicotinate ligands. Each cerium atom in $\mathbf{1}$ is nine-coordinate and exhibits a distorted mono-capped square antiprism geometry. The Ce(III) ions are coordinated by seven oxygen atoms of the carboxylate groups and two oxygen atoms of water molecules. In 2, each $\operatorname{Er}(\mathrm{III})$ ion is eight-coordinated adopting a distorted $\mathrm{ErO}_{8}$ dodecahedral geometry. The $\mathrm{Er}(\mathrm{III})$ ions are boundto four oxygen atoms of the chelating carboxylate ligands, to one oxygen each from the two bridiging carboxylates, and two oxygen atoms of water molecules. In 2 there is an intramolecular hydrogen bond forming a sixmembered ring between the $\mathrm{NH}_{2}$ group and one of the carboxylate oxygens in each of the six 2-
\end{abstract}


AMB ligands. In the crystal packing, the molecules of 1 and 2are associated through $\mathrm{O}($ or $\mathrm{N})-$ $\mathrm{H} \cdots \mathrm{O}$ and $\mathrm{O}-\mathrm{H} \cdots \mathrm{N}$ hydrogen bonds. In 2 the intermolecular hydrogen bonding results in a 3D supramolecular network structure.

Keywords: Cerium(III);Erbium(III) complexes; Nicotinic acid; 2-Aminobenzoic acid; Crystal Structures

*Corresponding authors (E-mail:saeed_a786@hotmail.com) 


\section{Introduction}

Lanthanide complexes with carboxylic acids have been studied extensively because of their interesting photophysical and structural properties [1-6] and due to their potential applications in various fields, e.g., luminescence [6-10], diagnostics [11,13], catalysis [13,14] and materials chemistry [15-20]. The lanthanide metals are defined as classical hard acids, and thus have a high affinity to bind with hard donors, for example, ligands containing oxygen atoms especially, carboxylates [8]. Due to the versatility of their coordination environments and applications, the lanthanide(III) complexes with carboxylate ligands have been widely studied [19-44]. The most common coordination number of M(III) ions is nine and carboxylates act as bidentate ligands. The crystal structures of these compounds are often characterized by strong hydrogen bonding [4-6,19-21].Aromatic carboxylic acids with two different coordinating atoms i.e., the nitrogen of a heterocyclic ring and carboxylic oxygen atoms, can coordinate with one or two other metal ions that can help in extending the structure by bridging [31-37]. The lanthanide complexes of such ligands, e.g.,isonicotinic acid and pyridine-2,6-dicarboxylic acid have shown an excellent bridging role in constructing novel MOFs with interesting optical and magnetic properties [3135].

We have previously reported the crystal structures of 2-aminobenzoate (2-AMB)-based chelates of $\mathrm{Ce}^{3+}, \mathrm{Pr}^{3+}[43]$ and $\mathrm{Yb}^{3+}$ [44]. In $\mathrm{Ce}^{3+}$ and $\mathrm{Pr}^{3+}$ complexes, the metal centers are ninecoordinate and exhibit distorted capped square anti-prismatic coordination geometries, while the $\mathrm{Yb}^{3+}$ complex possesses a distorted dodecahedral $\mathrm{YbO}_{8}$ environment. The change in coordination number can be related to the size of the metals. Ytterbium(III) being a smaller ion can accommodate fewer ligands. As an extension of our work in this line, the present report describes the synthesis and crystal structures of dinuclear complexes of cerium(III) and erbium(III) with nicotinic acid (NA) and 2-aminobenzoic acid (2-AMB) respectively, $\left[\mathrm{Ce}_{2}(\mathrm{NA})_{6}\left(\mathrm{H}_{2} \mathrm{O}\right)_{4}\right](\mathbf{1})$ and $\left[\mathrm{Er}_{2}(2-\mathrm{AMB})_{6}\left(\mathrm{H}_{2} \mathrm{O}\right)_{4}\right] \cdot 3 \mathrm{H}_{2} \mathrm{O}$, (2). The complexes were also analyzed by means of elemental analysis, infrared spectroscopy and thermal analysis (TG-DSC). The goal of the study is to provide the structural and stability information concerning these compounds in the solid state. The crystal structures of some cerium(III) [35,38] and erbium(III) [3942]complexes of similar carboxylate ligands are known in the literature. 


\section{Experimental}

\subsection{Reagents and Measurements}

Cerium(III) nitrate, $\mathrm{Ce}\left(\mathrm{NO}_{3}\right)_{3} \cdot 6 \mathrm{H}_{2} \mathrm{O}$ and erbium(III) chloride, $\mathrm{ErCl}_{3} \cdot 6 \mathrm{H}_{2} \mathrm{O}$ were purchased from Alfa Aesar, a Johnson Matthey Company, USA. Nicotinic acid (NA) and 2-aminobenzoic acid (2-AMB)were obtained from Merck Chemical Co. Germany. The IR spectra were recorded on a Perkin-Elmer FTIR 180 spectrophotometer using KBr pellets over the frequency range 4000-400 $\mathrm{cm}^{-1}$.Elemental analysis (CHN) was performed on Varion Micro Cube, Elementar, Germany. Thermal analysis was carried out using a Differential Scanning Calorimeter/Thermogravimeter Analyzer model SDT Q 600, TA Instruments, USA in a continuous nitrogen flow with a ramp rate of $10^{\circ} \mathrm{C}$ per minute. Alumina crucibles were used for recording the TG-DSC curves.

\subsection{X-ray structure determination}

Intensity data for complexes1and 2were recorded on a Bruker Kappa ApexII CCD detector diffractometer using graphite monochromated MoK $\alpha$ radiation $(\lambda=0.71073 \AA)$ at $296 \mathrm{~K}$. The refinement and all further calculations were carried out using SHELXL-2014 [45,46]. The aromatic $\mathrm{C}$ bound $\mathrm{H}$ atoms were geometrically located and refined as riding with $\mathrm{C}-\mathrm{H}=0.93 \AA$ and $U_{\text {iso }}(\mathrm{H})=1.2 \times U_{\text {eq }}(\mathrm{C})$. The $\mathrm{H}$ atoms of water molecules were found from difference Fourier maps $(\mathrm{N}-\mathrm{H}=0.85(6)-0.87(6), \mathrm{O}-\mathrm{H}=0.82(4)-0.84(4) \AA)$ and the isotropic atomic displacement parameters were fixed to 1.2 (for $\mathrm{N}$ ) or 1.5 (for $\mathrm{O}$ ) $\times U_{\text {eq }}$ of the parent atom. A summary of the crystallographic data and structure refinement is given in Table 1.

\subsection{Preparation of Complexes}

\subsection{1. $\left[\mathrm{Ce}_{2}(\mathrm{NA})_{6}\left(\mathrm{H}_{2} \mathrm{O}\right)_{4}\right]_{2}(\mathbf{1})$}

To a solution of $0.217 \mathrm{~g}(0.50 \mathrm{mmol})$ of $\mathrm{Ce}\left(\mathrm{NO}_{3}\right)_{3} \cdot 6 \mathrm{H}_{2} \mathrm{O}$ in $10 \mathrm{~mL}$ distilled water was added $0.184 \mathrm{~g}$ (1.50 mmol) nicotinic acid dissolved in $15 \mathrm{ml}$ ethanol. The solutions were mixed and stirred for one hour at room temperature. The mixture was filtered and the filtrate was kept at 
room temperature for crystallization. After 10 days, yellow crystals of $\mathbf{1}$ were recovered by vacuum filtration and were rinsed with ethanol.

\subsection{2. $\left[\mathrm{Er}_{2}(2-\mathrm{AMB})_{6}\left(\mathrm{H}_{2} \mathrm{O}\right)_{4}\right] \cdot 3 \mathrm{H}_{2} \mathrm{O}(2)$}

To a solution of $0.191 \mathrm{~g}(0.50 \mathrm{mmol})$ of $\mathrm{ErCl}_{3} \cdot 6 \mathrm{H}_{2} \mathrm{O}$ in $10 \mathrm{~mL}$ distilled water was added $0.205 \mathrm{~g}$ (1.50 mmol) 2-amino benzoic acid dissolved in $15 \mathrm{ml}$ ethanol. The $\mathrm{pH}$ of the solution was adjusted 5-6 with $1 \mathrm{M} \mathrm{NaOH}$. The solutions were mixed and stirred for one hour at room temperature. The mixture was filtered and the filtrate was kept at room temperature for crystallization. After 10 days, brown crystals of $\mathbf{2}$ were recovered by vacuum filtration and were rinsed with ethanol.

Analytical and spectroscopic data:(1). yield $=32 \%$. - Analysis for $\mathrm{CeC}_{18} \mathrm{H}_{16} \mathrm{~N}_{3} \mathrm{O}_{8}$ (542.46): calcd. C 39.81, H 2.94, N 7.74; found C 39.31, H 2.71, N 7.57. - IR (cm $\left.{ }^{-1}\right): v=3414(\mathrm{O}-\mathrm{H})$, 3071 (C-H), 1630, 1400 (COO), 1596, 1462, 1427(C=N, C=C). (Nicotinic acid, $v=3441(\mathrm{O}-\mathrm{H})$, 3070 (C-H), 1710, 1377, 1367 (COO), 1589, 1462, 1417 (C=N, C=C)).

(2). yield $=35 \%$. - Analysis for $\mathrm{Er}_{2} \mathrm{C}_{42} \mathrm{H}_{50} \mathrm{~N}_{6} \mathrm{O}_{19}$ (1277.40): calcd. C 39.48, H 3.94, N 6.58; found C 39.99, H 4.01, N 6.82. - IR $\left(\mathrm{cm}^{-1}\right): v=3469(\mathrm{O}-\mathrm{H}), 3367,3308(\mathrm{~N}-\mathrm{H}), 3073(\mathrm{C}-\mathrm{H})$, 1615, 1517, 1402 (COO), 1459 (C=C), 1260, 1160 (C-N); $\delta=1578$ (N-H). (2-AMB, $v=3612$ (O-H), 3387 (N-H), 3057 (C-H), 1671, 1418 (COO), 1488 (C=C), 1300, 1244, $1162(\mathrm{C}-\mathrm{N})$; $\delta$ = 1617, $1591(\mathrm{~N}-\mathrm{H}))$.

\section{Results and discussion}

\subsection{IR and thermal studies}

The complexes 1 and 2 were prepared by the reactions of $\mathrm{Ce}\left(\mathrm{NO}_{3}\right)_{3} \cdot 6 \mathrm{H}_{2} \mathrm{O}$ and $\mathrm{ErCl}_{3} \cdot 6 \mathrm{H}_{2} \mathrm{O}$ respectively with 1.5 equivalents of the corresponding carboxylic acid. In the IR spectrum of complex 1(shown in Figure S1, Supplementary Material), the intense peaks at $1630 \mathrm{~cm}^{-1}$ and $1400 \mathrm{~cm}^{-1}$ correspond to the asymmetric and symmetric stretching vibrations respectively, of the carboxyl group as observed for the coordinated carboxylate ligands [47]. When a carboxylic acid is protonated, the stretching frequency shifts to $1700 \mathrm{~cm}^{-1}$ and when it is deprotonated the 
frequency shifts towards $1600 \mathrm{~cm}^{-1}$. The $v(\mathrm{C}=\mathrm{O})$ vibration observed in the IR spectrum of nicotinic acid at $1710 \mathrm{~cm}^{-1}$ is absent in the spectrum of $\mathbf{1}$ suggesting the deprotonation of the carboxyl group [30].Absorption bands at 1596, 1462 and $1427 \mathrm{~cm}^{-1}$ are assigned to $v(\mathrm{C}=\mathrm{N})$ and $v(\mathrm{C}=\mathrm{C})$ modes of the pyridine ring. The $\mathrm{C}-\mathrm{H}$ stretching vibration appears at $3071 \mathrm{~cm}^{-1}$. A broad peak at $3414 \mathrm{~cm}^{-1}$ due to $-\mathrm{OH}$ vibrations indicates the presence of water molecules in the complex.

The IR spectrum of 2-aminobenzoic acid displays the N-H stretching vibrations of amino group at $3380 \mathrm{~cm}^{-1}$ and the bending vibration of $\mathrm{NH}_{2}$ at $1617 \mathrm{~cm}^{-1}$. The signal at $3612 \mathrm{~cm}^{-1}$ is associated with the O-H stretching of the carboxylic acid. The two medium stretching bands at 1671 and $1420 \mathrm{~cm}^{-1}$ correspond to the asymmetric and symmetric stretching vibration of the carboxylate group respectively. Furthermore, the band at $1488 \mathrm{~cm}^{-1}$ is attributed to theC $=\mathrm{C}$ stretching mode of the ring and the one at $1244 \mathrm{~cm}^{-1}$ could be ascribed to the C-N stretching vibration $[43,48,49]$.

In the spectrum of 2(shown in Figure S2, Suppl. Material), the band due to the $\mathrm{C}=\mathrm{O}$ vibration at $1671 \mathrm{~cm}^{-1}$ disappears entirely. The asymmetric and symmetric stretching vibrations respectively of the carboxylate group were observed at $1615 \mathrm{~cm}^{-1}$ and $1402 \mathrm{~cm}^{-1}$ respectively. The shift of $v_{\mathrm{as}} \mathrm{COO}^{-}$and $v_{\mathrm{s}} \mathrm{COO}^{-}$bands towards lower frequency supports the complexation of the carboxyl group of 2-AMB $[47,48]$.The signals at 3367, $3308 \mathrm{~cm}^{-1}$ mark the presence of the $\mathrm{NH}_{2}$ group. A broad peak at $3469 \mathrm{~cm}^{-1}$ is due to $-\mathrm{OH}$ vibrations, which suggests the presence of water molecules in the complex.

The pattern of thermal decomposition of the complexes was examined under an $\mathrm{N}_{2}$ atmosphere by means of thermogravimetric analysis (TGA) in the temperature range of 25-1100 ${ }^{\circ} \mathrm{C}$. The TGA curve of complex $\mathbf{1}$ is shown in Figure 1. It is divided into four consecutive and overlapping steps. The first weight loss of $6.5 \%$ in the temperature range $144-220{ }^{\circ} \mathrm{C}$ is attributed to the release of four coordinated water molecules (calcd weight loss 6.6\%). The second weight loss of $12 \%$ is in the temperature range $310{ }^{\circ} \mathrm{C}-425{ }^{\circ} \mathrm{C}$ corresponding to the release of one nicotinic acid group (theoretical value 11.25\%). In the third step, a $21 \%$ decrease in weight is observed at $425-550^{\circ} \mathrm{C}$, which represents the elimination of two nicotinic acid ligands (calculated $22.5 \%$ ). After $550{ }^{\circ} \mathrm{C}$ and until $1100{ }^{\circ} \mathrm{C}$ a weight loss of about $12 \%$ indicates the removal of one more nicotinate group but the decomposition is still incomplete. With a total weight loss of $51.5 \%$, the remaining residue of $48.5 \%$ includes the mass of two cerium atoms and two 
nicotinate ions (calculated value $48.3 \%$ ). The shape of the TGA curve is similar to those of the previously reported lanthanide(III) complexes of nicotinic acid [30].

The thermal decomposition of complex2 is represented by Figure S3 (Suppl. Material). The first weight loss of $9 \%$ in the temperature range $90-150^{\circ} \mathrm{C}$ is attributed to the removal of four coordinated and three uncoordinated water molecules (calcd. 8.9\%). In DSC this weight loss is indicated by an endothermic transition. After removal of the water molecules, a plateau indicates a thermally stable product of empirical formula [ $\left.\mathrm{Er}_{2}(2-\mathrm{AMB})_{6}\right]$.There is no chemical decomposition up to $310^{\circ} \mathrm{C}$. Above $310^{\circ} \mathrm{C}$, the second weight loss is due to the release of organic ligands and collapse of whole structure, which continues up to $950^{\circ} \mathrm{C}$. The final residue is $30 \%$ that is associated with $\mathrm{Er}_{2} \mathrm{O}_{3}$ (calcd. 29.9 \%). The shape of the TGA curve is similar to those of the previously reported $\mathrm{Ln}^{3+}$ complexes of 2-aminobenzoate [50]. The results of the thermogravimetric analysis indicate a good correlation between the calculated and found weight loss values for the investigated complex verifying its composition.

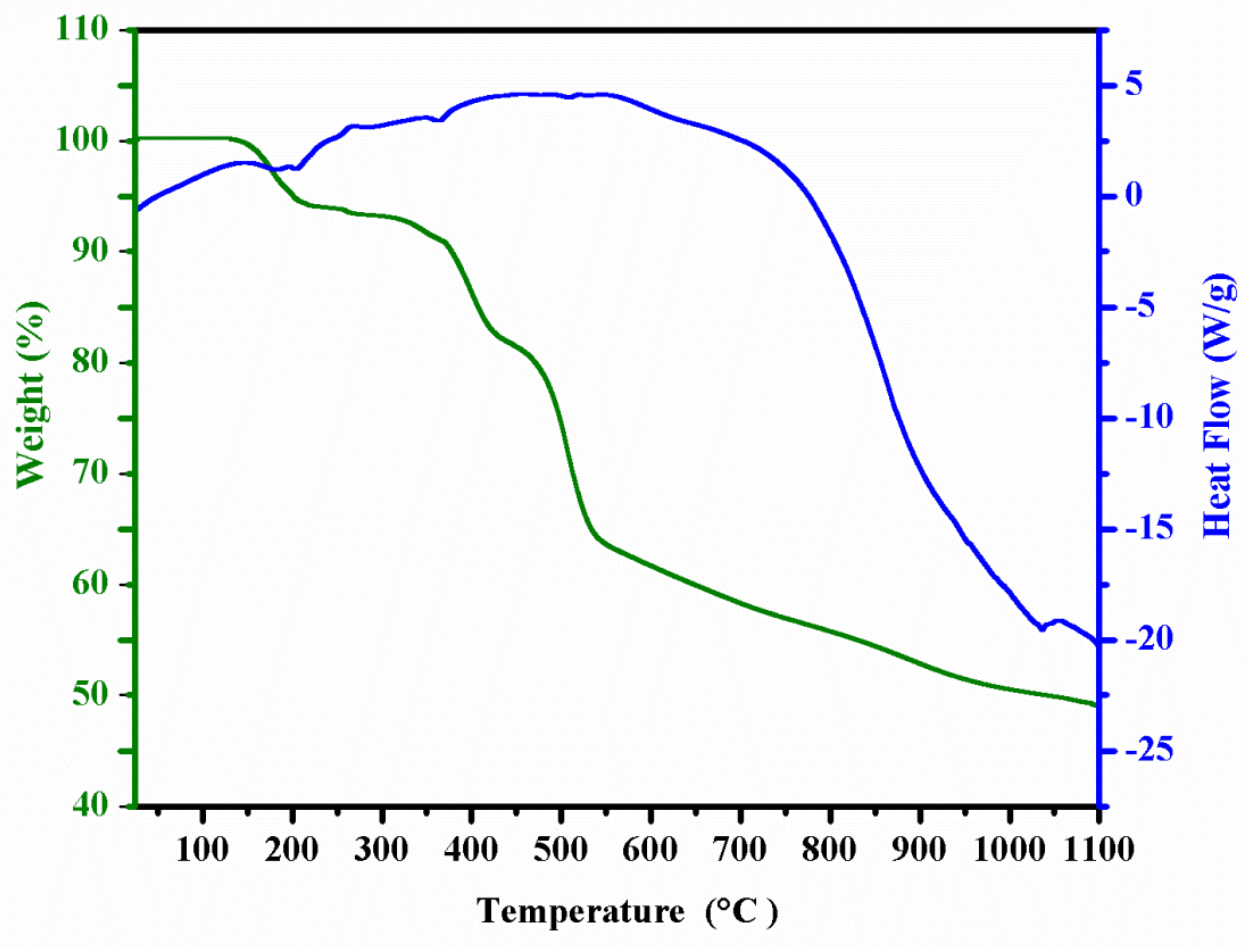

Fig. 1: TGA/DSC curves of $\left[\mathrm{Ce}_{2}(\mathrm{NA})_{6}\left(\mathrm{H}_{2} \mathrm{O}\right)_{4}\right]$ (1) 


\subsection{Description of $X$-ray structuresof 1 and 2}

The molecular structure of cerium(III) complex of nicotinic acid, $\left[\mathrm{Ce}_{2}\left(\mathrm{C}_{6} \mathrm{H}_{4} \mathrm{NO}_{2}\right)_{6}\left(\mathrm{H}_{2} \mathrm{O}\right)_{4}\right]$ (1) revealed by single-crystal X-ray diffraction analysis is depicted in Figure 2. The unit cell packing is shown in Figure S4. Significant bond lengths and bond angles for the metal coordination environment are presented in Table 2. The molecular structure of compound $\mathbf{1}$ consists of a homodinuclear species with two cerium atoms bridged by carboxylate groups of four deprotonated nicotinic acid molecules. Similar to other $\mathrm{Ln}^{+3}$ complexes of nicotinic acid [29-31], the dimeric structure of $\mathbf{1}$ possesses an inversion center of symmetry, indicating that both cerium centers reside in equivalent chemical environments. The Ce-Ce distance in $\mathbf{1}$ is 4.2092(3) $\AA$, which falls within the range observed for other $\mathrm{Ln}^{+3}$ nicotinate complexes that feature both bidentate and tridentate bridging coordination modes [29-32]. Each cerium atom is bound to nine oxygen donor atoms, seven of which are furnished by carboxylic groups of five nicotinic acid groups and the remaining two are provided by two water molecules. The coordination sphere can be described as highly distorted mono-capped square antiprism with [O(3), $\mathrm{O}(6), \mathrm{O}(7), \mathrm{O}(4)]$ and $\left[\mathrm{O}(3)^{\mathrm{i}}(\mathrm{i}=2-\mathrm{x}, 2-\mathrm{y}, 2-\mathrm{z}), \mathrm{O}(5), \mathrm{O}(8), \mathrm{O}(1)\right]$ as the bottom and top planes respectively, and atom $\mathrm{O}(2)$ forming the cap of the square as shown in Figure 3.

The higher coordination number of cerium is achieved with two bridging carboxylate groups adopting the terdentate bridging and chelating coordination modes. Nicotinate ions exhibit three different coordination modes to the cerium ions: a bidentate bridging $\left(\mu-\eta^{1}\right.$ : $\eta^{1}$ bidentate bridging), bidentate chelating ( $\eta^{2}$ chelating) and triply coordinate in which one oxygen atom of the chelate bridges the two cerium atoms of a dimer $\left(\mu-\eta^{2}: \eta^{1}\right.$ tridentate bridging). Such a bridging tridentate $\left(O, O, O^{\prime}\right)$ mode has been observed in the isostructural $\mathrm{Nd}(\mathrm{III})$ complex [32] as well as in $\mathrm{La}$ (III) [42] and Ce(III) [43] complexes of 2-aminobenzoic acid. As the rare-earth metals are typical hard acids, they are preferably coordinated by the carboxylate part of the nicotinate ligand forming stable complexes [29-32].The O-Ce-O bond angles range from $46.74^{\circ}(6)[\mathrm{O}(3)-\mathrm{Ce}(1)-\mathrm{O}(4)]$ to $151.55^{\circ}(6)$ [O(2)-Ce(1)-O(3)] in agreement with other cerium(III) complexes [35,38]. The longest Ce-O bond length involves the oxygen atom of one of the triply coordinated nicotinate ligands [Ce(1)-O(3), 2.933(2) $\AA$ ], which is due to the interaction of $\mathrm{O}(3)$ with the second cerium ion of the dimer, and the smallest angle [O(3)- 
$\left.\mathrm{Ce}(1)-\mathrm{O}(4), 46.74(6)^{\circ}\right]$ is the bite angle of a bidentate chelating nicotinate ligand. The Ce-O bond length for the chelating oxygen atoms [Ce(1)-O(1) 2.5395(19) $\AA$, Ce(1)-O(2) 2.6254(18) $\AA$, $\mathrm{Ce}(1)-\mathrm{O}(3)$ 2.933(2) $\AA$, $\mathrm{Ce}(1)-\mathrm{O}(4) 2.498(2) \AA]$ are larger than to the bridging oxygen atoms [Ce(1)-O(5) 2.4720(16) $\AA, \mathrm{Ce}(1)-\mathrm{O}(6)$ 2.4330(17) $\AA$, Ce(1)-O(3) 2.482(2) $\AA]$, which may be due to the fact that the small bite angles of the bidentate chelates [O(1)-Ce(1)-O(2) 50.02(6) and $\mathrm{O}(3)-\mathrm{Ce}(1)-\mathrm{O}(4) 46.74(6)^{\circ}$ ] weaken the Ce--O bonding interaction [31]. The Ce-O bond length for the water molecules are; $\mathrm{Ce}(1)-\mathrm{O}(7), 2.496(2) \AA$ and $\mathrm{Ce}(1)-\mathrm{O}(8), 2.4824(18) \AA$. The Ce-O bond lengths in 1are comparitivley longer than in the isostructural $\mathrm{Nd}(\mathrm{III})$ complex [32] because of the greater size of Ce(III).The crystal structure is stabilized by both intra- and intermolecular hydrogen bonding interactions. The geometric details of these hydrogen bonds are given in Table S1.The structure of the complex (1) is identical to the analogous $\mathrm{Nd}(\mathrm{III})$ complex of nicotinic acid [32]. But, it is different from the other related complexes of $\mathrm{La}(\mathrm{III}), \mathrm{Eu}(\mathrm{III}), \mathrm{Gd}(\mathrm{III}), \mathrm{Tb}(\mathrm{III})$, $\mathrm{Yb}$ (III) [29-31]. These complexes also consist of centrosymmetric dimeric molecules but the metal atoms are eight-coordinated. The six nicotinato ligands are coordinated with the central atom in the bidentate mode via both oxygen atoms of the carboxylate group. The coordination sphere is completed by two water molecules bonded in the cis mode. The coordination polyhedron is a slightly distorted, bicapped trigonal prism. The decrease in coordination number from nine (in case of ceriumin 1) to eight for the others can be related to the lanthanide contraction [42].

The analogous complexes of isonicotinic acid (pyridine-4-carboxylic acid) are usually polymeric e.g., $\left[\mathrm{Nd}_{3}\left(\text { isonicotinic) }{ }_{9}\left(\mathrm{H}_{2} \mathrm{O}\right)_{6}\right]_{n}\right.$ [32]. Like nicotinic acid (pyridine-3-carboxylic acid), isonicotinic acid coordinates only through carboxylate oxygen atoms possessing the bridging $(O, O)$ mode [31-33].However, the crystal structures of pyridine-2-carboxylic acid (picolinic acid) complexes with lanthanide differ from those of nicotinic acid and isonicotinic acid in that the ring nitrogen atom is able to coordinate to lanthanide ion [38,39]. Thus the complexes are stabilized by the chelate effect. For example, the cerium(III) and erbium(III) complexes of picolinic acid (pic) exist as anionic complexes ([Ce(pic) $)_{5}^{2-}$ and $\left.\left[\operatorname{Er}(\text { pic })_{4}\right]^{-}\right)$, in which all five or four picolinates are coordinating to the metal atom in $N$, $O$-chelating mode $[38,39]$.

The molecular structure of $\left[\operatorname{Er}_{2}(2-\mathrm{AMB})_{6}\left(\mathrm{H}_{2} \mathrm{O}\right)_{4}\right] \cdot 3 \mathrm{H}_{2} \mathrm{O}$ (2)is shown in Figure 4. The selected bond lengths and angles are listed in Table 3. The compound is composed of a dinuclear complex and three water molecules of crystallization. The dimeric molecule is located on a 
center of symmetry. Each erbium(III)ion in the complex adopts a distorted dodecahedral geometry and is coordinated by two $\mathrm{O}$ atoms from water molecules and six $\mathrm{O}$ atoms from 2AMB groups (two from bidentate bridging carboxylates and four from bidentate chelating carboxylates). In each dinuclear molecule, the two erbium centers are bridged by two carboxylate ligands to form an eight-membered ring. The Er*Er distance of 5.1069(4) $\AA$ is somewhat longer than that found in other erbium(III) complexes [40,41]. The Er-O bond lengths range from 2.219(3) to 2.437(4) $\AA$ with an average value of $2.345 \AA$, which is comparable with those in other, similar eight coordinated Er(III) complexes [39-42]. The Er-O bond lenghts of bidentate chelating carboxylates are longer [( $\operatorname{Er}(1)-\mathrm{O}(1)$ 2.368(3), $\operatorname{Er}(1)-\mathrm{O}(2)$ 2.437(4), $\operatorname{Er}(1)-$ $\mathrm{O}(3)$ 2.427(3), $\operatorname{Er}(1)-\mathrm{O}(4) 2.350(3)]$ than to the bridging carboxylate oxygens $[\operatorname{Er}(1)-O(5)$ 2.259(4), $\left.\operatorname{Er}(1)-O(6)^{i i} 2.219(3)\right](i i=-x+1,-y+1,-z)$. This is due to the fact that the small bite angles $\left[\mathrm{O}(1)-\operatorname{Er}(1)-\mathrm{O}(2) 53.95(11)\right.$ and $\left.\mathrm{O}(3)-\operatorname{Er}(1)-\mathrm{O}(4) 54.05(11)^{\circ}\right]$ in the bidentate chelating ligands weakens the Er--O bonding interactions as seen above in the Ce complex [27].

The $\mathrm{N}$ atoms of $\mathrm{NH}_{2}$ groups of 2-AMB ligands do not coordinate with $\mathrm{Er}^{3+}$ ions. However, they are important in the structure since they participate in the formation of intramolecular hydrogen bonds with a carboxylate oxygen in the same ligand, stabilizing the approximately planar conformation of each ligand. Dimeric complex molecules are linked into $\mathrm{H}$-bonded sheets in the $a / b$ plane via $\mathrm{H}$-bonds between water molecules, carboxylate oxygens and $\mathrm{NH}_{2}$ groups as shown in FigureS5. The hydrogen bonding details are given in Table S1. Three disordered water molecules of crystallization were modelled by the Platon squeeze procedure [51]. Squeeze recovered 29 electrons per unit cell in one void. Water has 10 electrons, so this electron density was interpreted as three water molecules. The complex is isotypic with the analogous erbium(III) complex of 4-aminobenzoic acid [41]. The structure of the complex is also very similar to other dinuclear lanthenide complexes of aminobenzoates such as, $\left[\mathrm{Er}_{2}(2-\right.$ AMB $\left.)_{6}\left(\mathrm{H}_{2} \mathrm{O}\right)_{4}\right] \cdot 2 \mathrm{H}_{2} \mathrm{O}$ [42], $\left[\mathrm{Yb}_{2}(2-\mathrm{AMB})_{6}\left(\mathrm{H}_{2} \mathrm{O}\right)_{4}\right] \cdot 2 \mathrm{C}_{2} \mathrm{H}_{5} \mathrm{OH}$ and $\left[\mathrm{Yb}_{2}(3-\mathrm{AMB})_{6}\left(\mathrm{H}_{2} \mathrm{O}\right)_{4}\right] \cdot 3 \mathrm{H}_{2} \mathrm{O}$ [44]. The $\left[\mathrm{Ln}(2-\mathrm{AMB})_{3}\right]_{\mathrm{n}}$ complexes with $\mathrm{Ln}=\mathrm{La}(\mathrm{III}), \mathrm{Ce}(\mathrm{III})$ and $\operatorname{Pr}(\mathrm{III})$; exist as polymers having nine coordinate lanthanide atoms and bridging tridentate $\left(O, O, O^{\prime}\right)$ 2-AMB ligands $[42,43]$, whereas $\left[\mathrm{Nd}(2-\mathrm{AMB})_{3}\left(\mathrm{H}_{2} \mathrm{O}\right)_{3}\right] \cdot 3 \mathrm{H}_{2} \mathrm{O}$ is monomeric with nine coordinate neodymium and solely chelating $(O, O)$ 2-AMB groups [42]. The ytterbium complex, [ $\left.\mathrm{Yb}(2-\mathrm{AMB})_{3}\left(\mathrm{H}_{2} \mathrm{O}\right)\right]_{\mathrm{n}}$ is polymeric with bridging bidentate $(O, O$ ') ligands and seven coordinated metal atom [42]. As the lanthanide(III) ions are typical hard acids, in the all above-mentioned structures, the 2-AMB 
ligand is coordinated to the lanthanide solely through the carboxylate group, in contrast to carboxylate and $\mathrm{NH}_{2}$ coordination (chelation) found in transition metal complexes of 2aminobenzoate [52,53]. Although the amino group is not bound to the lanthanide cations, it participates in stabilization of hydrogen bonded networks [41,42]. 


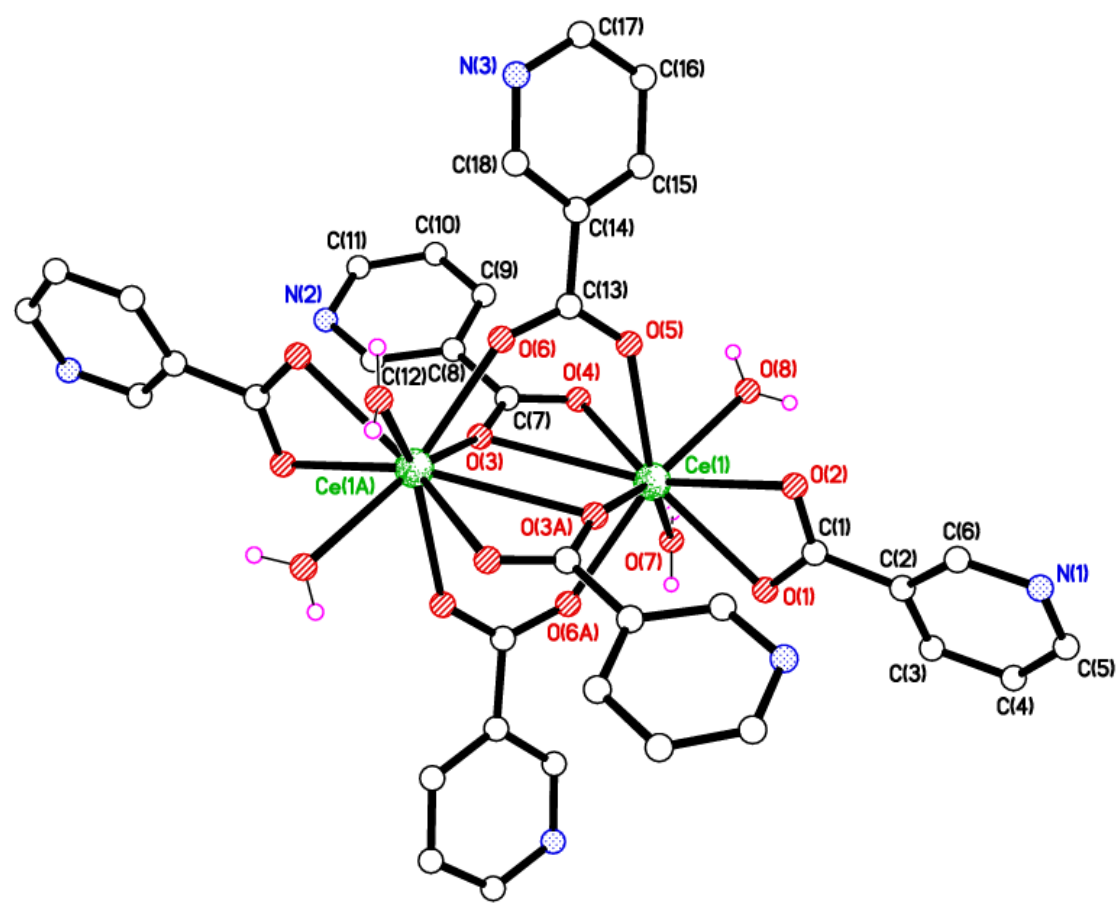

Fig. 2.Molecular structure diagram of 1.Hydrogen atoms except those on water ligands are ommited for clarity.Symmetry code: (i) $=2-x, 2-y, 2-z$. 


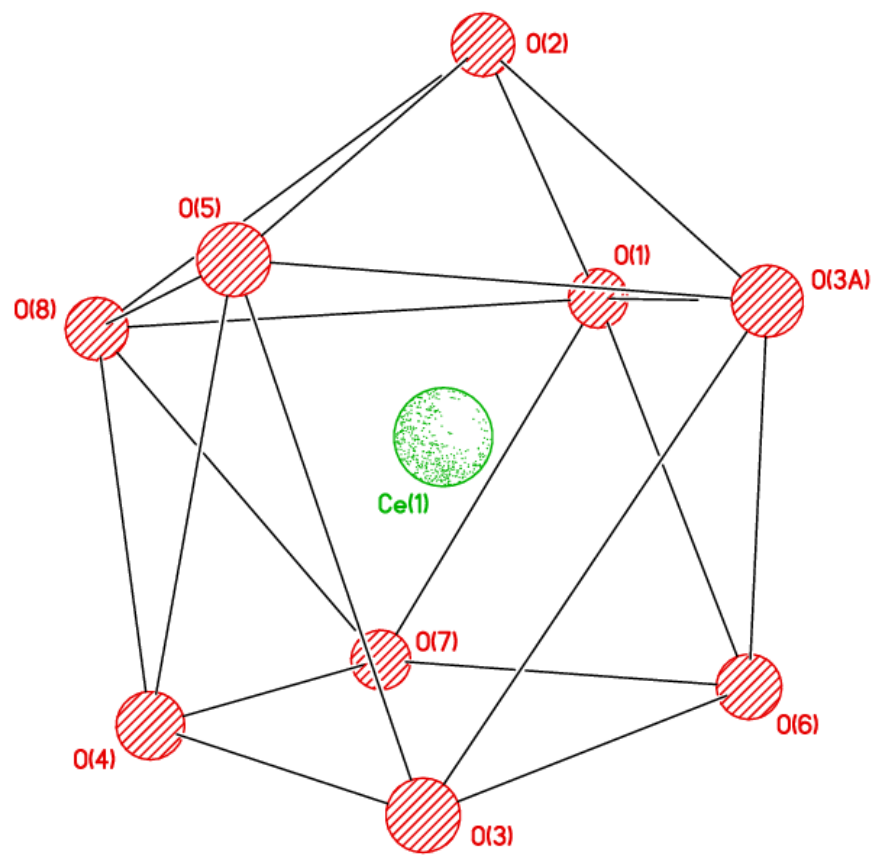

Fig. 3.A View of the distorted mono-capped square antiprism formed by the coordinated ligand atoms around the Ce atom in $\mathbf{1 .}$ 


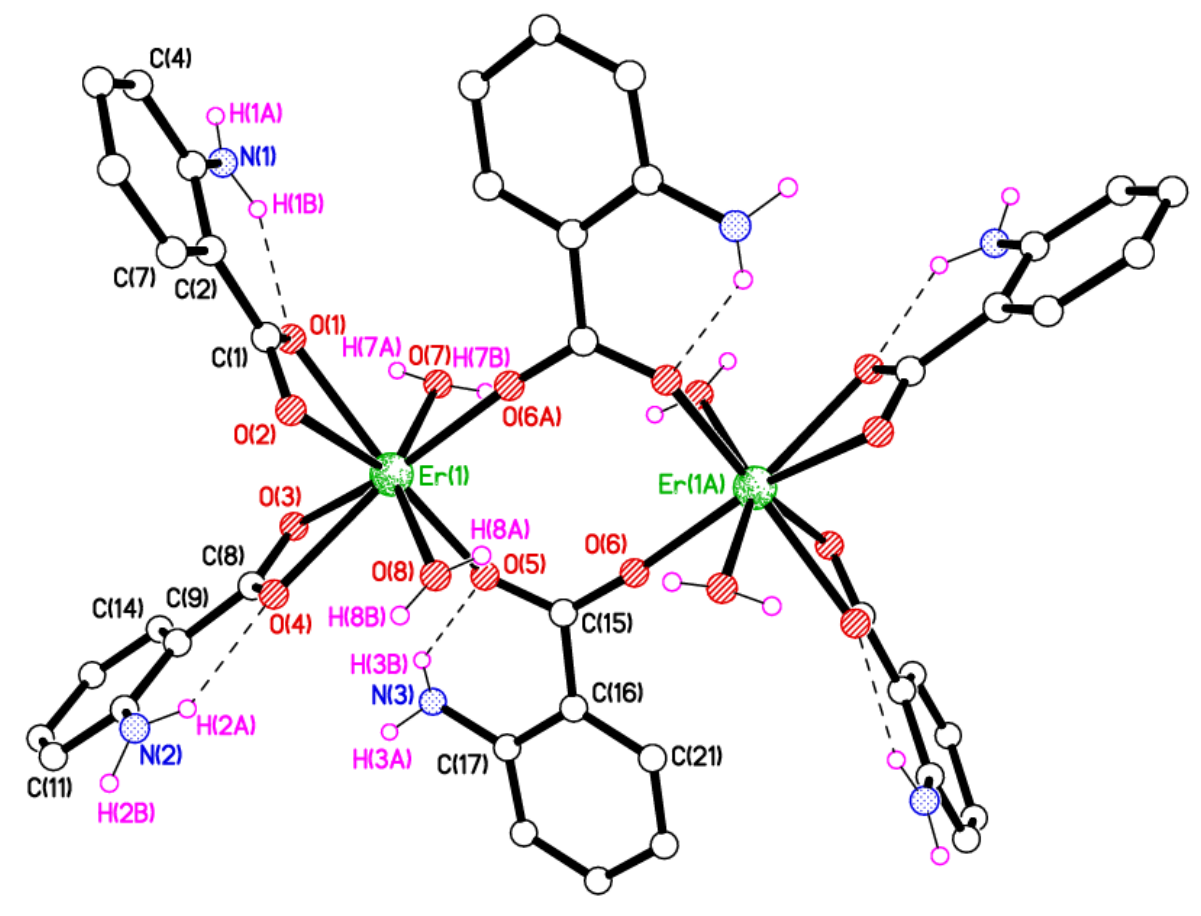

Fig. 4.Molecular structure of2.Non-coordinated water molecules and C-bound $\mathrm{H}$ atoms of 2aminobenzoic acid are omitted of clarity. 


\section{Conclusion}

In conclusion, we present the synthesis and molecular structures of two new dinuclear cerium(III) and erbium(III) complexes with nicotinic acid and 2-aminobenzoic acid respectively. Thermal decomposition of the complexes was studied by thermogravimetric analysis and the results verify the composition of the complexes. In case of compound 2, lanthanide oxide was identified as the final product, but for $\mathbf{1}$ the decomposition is incomplete until $1100{ }^{\circ} \mathrm{C}$ indicating its high thermal stability. In the cerium(III) complex, $\left[\mathrm{Ce}_{2}(\mathrm{NA})_{6}\left(\mathrm{H}_{2} \mathrm{O}\right)_{4}\right](\mathbf{1})$ the central $\mathrm{Ce}^{3+}$ ions are nine-coordinate and assume a distorted mono-capped square antiprism geometry. In the erbium(III) complex, $\left[\mathrm{Er}_{2}(2-\mathrm{AMB})_{6}\left(\mathrm{H}_{2} \mathrm{O}\right)_{4}\right] \cdot 3 \mathrm{H}_{2} \mathrm{O}(2)$, the $\mathrm{Er}^{3+}$ ion sare eight-coordinated adopting a distorted dodecahedral geometry. The hydrogen bonding pattern in 2 results in a 3D supramolecular network structure in the solid state. The variation in coordination number from nine (for $\mathrm{Ce}^{3+}$ ) to eight (for $\mathrm{Er}^{3+}$ ) can be related to the lanthanide contraction, The carboxylate groups of the nicotinate ligands exhibited three different binding modes, chelating, bridging bidentate and bridging tridentate, while 2-AMB acts only as chelating and bridging bidentate ligand. The amino group of 2-AMB ligand is not coordinated to the erbium(III)cation. The structural features of $\mathbf{1}$ and $\mathbf{2}$ are very similar to those of related complexes.

\section{Supplementary data}

Supplementary data related to this article can be found in the online version.CCDC Nos. 1043894 and 1819054 contain the crystallographic data for the structures of $\mathbf{1}$ and $\mathbf{2}$ respectively. The data can be obtained free of charge from the Cambridge Crystallographic Data Centre viawww.ccdc.cam.ac.uk/data_request/cif.

\section{Acknowledgments}

Sajjad Hussain greatfully acknowledges the Higher Education Commission (HEC) of Pakistan for providing the financial support through Indigenious Fellowship and International Research Support Iniative Programs. 


\section{References}

1. Y.-L. Gai, F.-L. Jiang, L. Chen, Y. Bu, K.-Z. Su, S. A. Al-Thabaiti, M.-C. Hong, Inorg. Chem. 52 (2013) 7658-7665.

2. $\quad$ B. Yan, H. Zhu, J. Fluorescence 17 (2007) 331-337.

3. L.-N. Sun, J.-B. Yu, G.-L. Zheng, H.-J. Zhang, Q.-G. Meng, C.-Y. Peng, L.-S. Fu, F.-Y. Liu, Y.-N. Yu, Eur. J. Inorg. Chem. 19 (2006) 3962-3973.

4. H.-J. Chen, X.-M. Chen, Inorg. Chim. Acta 329 (2002) 13-21.

5. C. M. G. dos Santos, A. J. Harte, S. J. Quinn, T. Gunnlaugsson, Coord. Chem. Rev. 252 (2008) 2512-2527.

6. Y.-W. Wang, Y.-L. Zhang, W. Dou, A.-J. Zhang, W.-W. Qin, W.-S. Liu, Dalton Trans. 39 (2010) 9013-9021.

7. Q. Sun, P. Yan, W. Niu, W. Chu, X. Yao, G. An, G. Li, RSC Adv. 81 (2015) 6585665861

8. M. C. Heffen, L. M. Matosziuk, T. J. Meade, Chem. Rev. 114 (2014) 4496-4539.

9. S. Faulkner, S. J. A. Pope, B. P. Burton-Pye, Appl. Spectr. Rev. 40 (2005) 1-31.

10. A. Dossing, Eur. J. Inorg. Chem. 8 (2005) 1425-1434.

11. V. W.-W. Yam, K. K.-W. Lo, Coord. Chem. Rev. 184 (1999) 157-240.

12. I. Hemmila, V.-M. Mukkala, H. Takalo, J. Alloys Comp. 249 (1997) 158-162.

13. M. Shibasaki and N. Yoshikawa, Chem. Rev. 102 (2002) 2187-2209.

14. C. Pagis, M. Ferbinteanu, G. Rothenberg, S. Tanase, ACS Catalysis 6 (2016) 6063-6072.

15. D. Fan, X. Fei, J. Tian, L. Xu, X. Wang, S. Fan, Y. Wang, Polym. Chem. 6 (2015) 5430-5436.

16. C. Reinhard, H. U. Güdel, Inorg. Chem. 41 (2002) 1048-1055.

17. K. Binnemans, Chem. Rev. 109 (2009) 4283-4374.

18. M. A. Katkova, M. N. Bochkarev, Dalton Trans. 39 (2010) 6599-6612.

19. J. Tian, B. Li, X. Zhang, X. Li, J. Zhang, Dalton Trans. 42 (2013) 8504-8511.

20. J. Ye, Q. Wang, H.Gao, X. Lu, W. Gong, Y. Lin, G. Ning, Inorg. Chim. Acta 384 (2012) $1-7$.

21. Y. Xie, Y.-H. Xing, Z. Wang, H.-Y. Zhao, X.-Q. Zeng, M.-F. Ge, S.-Y. Niu, Inorg. Chim. Acta 363 (2010) 918-924. 
22. K. E. Chrysomallidou, S. P. Perlepes, A. Terzis, C. P. Raptopoulou, Polyhedron 29 (2010) 3118-3124.

23. L. Oyang, H.-L. Sun, X.-Y. Wang, J.-R. Li, D.-B. Nie, W.-F. Fu, S. Gao, K.-B. Yu, J. Mol. Struct. 740 (2005) 175-180.

24. L. Zhao, Y. Chen, H. Zhang, C. Li, R. Sun, Q. Yang, J. Mol. Struct. 920 (2009) 441-449.

25. R. Feng, F.-L. Jiang, M.-Y. Wu, L. Chen, C.-F. Yan, M.-C. Hong, Cryst. Growth Des. 10 (2010) 2306-2313.

26. C.-H. Ye, H.-L. Sun, X.-Y. Wang, J.-R. Li, D.-B. Nie, W.-F. Fu, S. Gao, J. Solid State Chem. 177 (2004) 3735-3742.

27. J.-G. Mao, H.-J. Zhang, J.-Z. Ni, S.-B. Wang, T. C. W. Mak, Polyhedron 17 (1998) 39994009.

28. Q. B. Bo, Z. X. Sun, Y. L. Sheng, Z. W. Zhang, G. X. Sun, C. L. Chen, Y. X. Li, D. Q. Wang, Struc. Chem. 17 (2006) 609-615.

29. J. W. Moore, M. D. Glick, J. W. Baker Jr., J. Am. Chem. Soc. 94 (1972) 1858-1865.

30. N. Hojnik, M. Kristl, A. Golobic, Z. Jaglicic, M. Drofenik, Cent. Eur. J. Chem. 12 (2014) 220-226.

31. G. Jia, G.-L. Law, K.-L., Wong, P.-A., Tanner, W.-T. Wong, Inorg. Chem. 47 (2008) 9431-9438.

32. S. Sharma, M. Yawer, M. Kariem, R. Singh, H. N. Sheikh, Russ. J. Coord. Chem. 41 (2015) 469-480.

33. L. Han, X. Sun, Y. Zhu, W. Zhou, Q. Chen, Y. Xu, J. Chem.Crystallogr. 40 (2010)579582.

34. B. Ay, E. Yildiz, I. Kani, Polyhedron 142 (2018) 1-8.

35. S. Sharif, I. U. Khan, O. Şahin, S. Ahmad, O. Büyükgüngör, S. Ali, J. Inorg. Organomet. Polym. Mater. 22 (2012) 1165-1173.

36. P. A. Brayshaw, A. K. Hall, W. T. A. Harrison, J. M. Harrowfield, D. Pearce, T. M. Shand, B. W. Skelton, C. R. Whitaker, A. H. White, Eur. J. Inorg. Chem. (2005) 11271141.

37. Z. Wang, F.-Y. Bai, Y.-H. Xing, Y. Xie, X.-Q. Zeng, M.-F. Ge, S.-Y. Niu, J. Inorg. Organomet. Poly. Mat. 20 (2010) 242-249. 
38. Y. Oh, J. Y. Kim, H. J. Kim, T. Lee, S. K. Kang, Bull. Korean Chem. Soc. 31 (2010) 1058.

39. P. C. R. Soares-Santos, H. I. S. Nogueira, V. Felix, M.l G.B. Drew, R. A. Sa Ferreira, L. D. Carlos, T. Trindade, Inorg. Chem. Commun. 6 (2003) 1234-1238.

40. J.P. Costes, J.M. Clemente-Juan, F. Dahan, F. Nicodeme, M. Verelst, Angew. Chem. Int. Ed. 41 (2002) 323.

41. G. Smith, and D. E. Lynch, Acta Cryst. E71 (2015) 1457-1461.

42. G.B. Deacon, M. Forsyth, P. C. Junk, S. G. Leary, G. J. Moxey, Polyhedron 25 (2006) 379-386.

43. S. Hussain, I. U. Khan, W. T. A. Harrison, M. N.Tahir, S. Ahmad, J. Struct. Chem. 56 (2015) 126-133.

44. S. Hussain, I. U. Khan, M. Akkurt, S. Ahmad, M. N. Tahir, Russ. J. Coord. Chem. 40 (2014) 686-694.

45. G. M. Sheldrick, Acta Cryst. A64 (2008) 112-122.

46. G. M. Sheldrick, Acta Cryst. C71 (2015) 3-8.

47. G. B. Deacon, R. J. Philips, Coord. Chem. Rev. 33 (1980) 227-250.

48. W. Brzyska, Z. Rzczyfiska, Monatsh. Chemie 119 (1988) 147-156.

49. A. A. Essawy, M. A. Afifi, H. Moustafa, S.M. El-Medani, SpectrochimicaActa A: Mol. Biomol. Spectr. 131 (2014) 388-397.

50. W. Brzyska, Z. Rzączyńska, J. Therm Anal. 32 (1987) 1355-1359.

51. B.A. Lange, R.A. Haendler, H.M. Haendler, J. Solid State Chem. 15 (1975) 325.

52. $\quad$ S.M. Boudreau, R.A. Boudreau, H.M. Haendler, J. Solid State Chem. 49 (1983) 379.

53. A.L. Spek, Acta Cryst. C71(2015) 9-18. 
Table 1 Summary of crystal data and refinement details for compounds $\mathbf{1}$ and $\mathbf{2}$

\begin{tabular}{|c|c|c|}
\hline Compound & 1 & 2 \\
\hline Formula & $\mathrm{C}_{18} \mathrm{H}_{16} \mathrm{~N}_{3} \mathrm{O}_{8} \mathrm{Ce}$ & $\mathrm{C}_{42} \mathrm{H}_{50} \mathrm{~N}_{6} \mathrm{O}_{19} \mathrm{Er}_{2}$ \\
\hline Formula Weight & 542.46 & 1277.40 \\
\hline Crystal system & Monoclinic & Triclinic \\
\hline Space Group & $P 2_{1} / c$ & $P \overline{1}$ \\
\hline$a, b, c, \AA$ & $\begin{array}{l}\text { 9.7330(5), 12.1009(6), } \\
17.0581(9)\end{array}$ & $\begin{array}{l}9.1339(4), 11.8565(6), \\
12.8990(6)\end{array}$ \\
\hline$\alpha, \beta, \gamma\left(^{\circ}\right)$ & 90, 92.658(2), 90 & $\begin{array}{l}\text { 96.388(2), 94.993(3), } \\
112.404(2)\end{array}$ \\
\hline$V, \AA^{3}$ & 2006.91(18) & $1270.65(11)$ \\
\hline$Z$ & 4 & 1 \\
\hline$\rho_{\text {calc }}, \mathrm{g} \mathrm{cm}^{-3}$ & 1.795 & 1.669 \\
\hline$\mu(\mathrm{MoK} \alpha), \mathrm{mm}^{-1}$ & 2.32 & 3.36 \\
\hline $\mathrm{F}(000)$ & 1068 & 632 \\
\hline Crystal size, $\mathrm{mm}^{3}$ & $0.42 \times 0.28 \times 0.26$ & $0.36 \times 0.22 \times 0.20$ \\
\hline Temperature, K & 296 & 296 \\
\hline$\lambda \operatorname{MoK} \alpha, \AA$ & 0.71073 & 0.71073 \\
\hline$\theta$ range, deg & $2.1-27.1$ & $2.4-25.5^{\circ}$ \\
\hline$h, k, l$ limits & $-12: 12,-15: 13,-20: 21$ & $-10: 11,-14: 14,-15: 15$ \\
\hline Reflections, collected/unique & $15620 / 4371$ & 18358 / 4708 \\
\hline observed reflections $[I>2 \sigma(I)]$ & 3867 & 4049 \\
\hline$R_{\text {int }}$ & 0.024 & 0.046 \\
\hline $\mathrm{T}_{\max } / \mathrm{T}_{\min }$ & $0.584 / 0.443$ & $0.553 / 0.378$ \\
\hline Data / restraints / parameters & $4371 / 283 / 4$ & 4708 / 15 / 328 \\
\hline Goodness of fit on $F^{2}$ & 1.12 & 1.01 \\
\hline$R\left[F^{2}>2 \sigma\left(F^{2}\right)\right], w R\left(F^{2}\right)$ & $0.021,0.056$ & $0.035,0.080$ \\
\hline Largest diff. peak/hole (e $\AA^{-3}$ ) & $0.75 /-0.52$ & $1.99 /-0.86$ \\
\hline
\end{tabular}


Table 2: Selected bond lengths ( $\AA$ ) and bond angles (deg) for $\mathbf{1}$

\begin{tabular}{llll}
\hline Bond length & \multicolumn{3}{l}{ Bond angle } \\
\hline $\mathrm{Ce}(1)-\mathrm{O}(1)$ & $2.5395(19)$ & $\mathrm{O}(1)-\mathrm{Ce}(1)-\mathrm{O}(2)$ & $50.02(6)$ \\
$\mathrm{Ce}(1)-\mathrm{O}(2)$ & $2.6254(18)$ & $\mathrm{O}(1)-\mathrm{Ce}(1)-\mathrm{O}(3)$ & $150.53(6)$ \\
$\mathrm{Ce}(1)-\mathrm{O}(3)$ & $2.933(2)$ & $\mathrm{O}(2)-\mathrm{Ce}(1)-\mathrm{O}(3)$ & $151.55(6)$ \\
$\mathrm{Ce}(1)-\mathrm{O}\left(3^{\mathrm{i}}\right)$ & $2.482(2)$ & $\mathrm{O}\left(3^{\mathrm{i}}\right)-\mathrm{Ce}(1)-\mathrm{O}(1)$ & $95.59(7)$ \\
$\mathrm{Ce}(1)-\mathrm{O}(4)$ & $2.498(2)$ & $\mathrm{O}\left(3^{\mathrm{i}}\right)-\mathrm{Ce}(1)-\mathrm{O}(3)$ & $78.30(7)$ \\
$\mathrm{Ce}(1)-\mathrm{O}(5)$ & $2.4720(16)$ & $\mathrm{O}(4)-\mathrm{Ce}(1)-\mathrm{O}(1)$ & $138.94(8)$ \\
$\mathrm{Ce}(1)-\mathrm{O}\left(6^{\mathrm{i}}\right)$ & $2.4330(17)$ & $\mathrm{O}(4)-\mathrm{Ce}(1)-\mathrm{O}(2)$ & $141.98(7)$ \\
$\mathrm{Ce}(1)-\mathrm{O}(7)$ & $2.496(2)$ & $\mathrm{O}(4)-\mathrm{Ce}(1)-\mathrm{O}(3)$ & $46.74(6)$ \\
$\mathrm{Ce}(1)-\mathrm{O}(8)$ & $2.4824(18)$ & $\mathrm{O}(5)-\mathrm{Ce}(1)-\mathrm{O}(3)$ & $71.33(6)$ \\
$\mathrm{O}(1)-\mathrm{C}(1)$ & $1.254(3)$ & $\mathrm{O}(5)-\mathrm{Ce}(1)-\mathrm{O}(7)$ & $141.24(6)$ \\
$\mathrm{O}(2)-\mathrm{C}(1)$ & $1.247(3)$ & $\mathrm{O}\left(6^{\mathrm{i}}\right)-\mathrm{Ce}(1)-\mathrm{O}(1)$ & $80.75(7)$ \\
$\mathrm{O}(3)-\mathrm{C}(7$ & $1.258(3)$ & $\mathrm{O}\left(6^{\mathrm{i}}-\mathrm{Ce}(1)-\mathrm{O}(7)\right.$ & $71.43(8)$ \\
$\mathrm{O}(4)-\mathrm{C}(7)$ & $1.241(3)$ & $\mathrm{O}(7)-\mathrm{Ce}(1)-\mathrm{O}(4)$ & $71.71(7)$ \\
$\mathrm{O}(5)-\mathrm{C}(13)$ & $1.251(3)$ & $\mathrm{O}(8)-\mathrm{Ce}(1)-\mathrm{O}(4)$ & $70.81(7)$ \\
$\mathrm{O}(6)-\mathrm{C}(13)$ & $1.252(3)$ & $\mathrm{O}(8)-\mathrm{Ce}(1)-\mathrm{O}(7)$ & $74.65(7)$ \\
\hline $\mathrm{S}$ & & &
\end{tabular}

Symmetry code: (i) $-x+2,-y+2,-z+2$. 
Table 3: Selected bond lengths ( $\AA$ ) and bond angles (deg) for2

\begin{tabular}{llll}
\hline Bond length & \multicolumn{3}{l}{ Bond angle } \\
\hline $\operatorname{Er}(1)-\mathrm{O}(1)$ & $2.368(3)$ & $\mathrm{O}(1)-\operatorname{Er}(1)-\mathrm{O}(2)$ & $53.95(11)$ \\
$\operatorname{Er}(1)-\mathrm{O}(2)$ & $2.437(4)$ & $\mathrm{O}(1)-\operatorname{Er}(1)-\mathrm{O}(3)$ & $83.20(12)$ \\
$\operatorname{Er}(1)-\mathrm{O}(3)$ & $2.427(3)$ & $\mathrm{O}(3)-\operatorname{Er}(1)-\mathrm{O}(2)$ & $110.53(12)$ \\
$\operatorname{Er}(1)-\mathrm{O}(4)$ & $2.350(3)$ & $\mathrm{O}(4)-\operatorname{Er}(1)-\mathrm{O}(3)$ & $54.05(11)$ \\
$\operatorname{Er}(1)-\mathrm{O}(5)$ & $2.259(4)$ & $\mathrm{O}(4)-\operatorname{Er}(1)-\mathrm{O}(2)$ & $79.50(13)$ \\
$\operatorname{Er}(1)-\mathrm{O}\left(6^{\mathrm{i}}\right)$ & $2.219(3)$ & $\mathrm{O}(5)-\operatorname{Er}(1)-\mathrm{O}(1)$ & $149.85(13)$ \\
$\operatorname{Er}(1)-\mathrm{O}(7)$ & $2.356(3)$ & $\mathrm{O}(5)-\operatorname{Er}(1)-\mathrm{O}(4)$ & $89.03(14)$ \\
$\operatorname{Er}(1)-\mathrm{O}(8)$ & $2.346(3)$ & $\mathrm{O}\left(6^{\mathrm{i}}\right)-\operatorname{Er}(1)-\mathrm{O}(4)$ & $151.08(13)$ \\
& & $\mathrm{O}\left(6^{\mathrm{i}}\right)-\operatorname{Er}(1)-\mathrm{O}(5)$ & $96.50(13)$ \\
& & $\mathrm{O}(7)-\operatorname{Er}(1)-\mathrm{O}(1)$ & $72.30(14)$ \\
& & $\mathrm{O}(8)-\operatorname{Er}(1)-\mathrm{O}(3)$ & $122.94(13)$
\end{tabular}

Symmetry code: (i) $-x+1,-y+1,-z$. 